\title{
Variações da qualidade da água de chuva e de açudes armazenada em cisternas em municípios do semiárido do estado da Paraíba
}

\author{
Variations in the quality of rainwater and fluvial reservoirs stored \\ in cisterns in municipalities of the semiarid region of Paraiba State
}

\author{
Cindy Deina Farto ${ }^{1}$, Tarciso Cabral da Silva** ${ }^{1 *}$
}

\begin{abstract}
RESUMO
Neste trabalho são apresentadas a evolução temporal de parâmetros de qualidade e a análise de conformidade da água armazenada em cisternas nos municípios de Barra de Santana, Boqueirão e Caturité, no semiárido do estado da Paraíba. A água armazenada nas cisternas estudadas é oriunda da chuva e dos açudes Epitácio Pessoa, na região do Cariri, e Araçagi, na região do Brejo. Foram analisados os valores dos parâmetros $\mathrm{pH}$, turbidez, condutividade elétrica, sólidos totais dissolvidos, alcalinidade total, cor aparente, dureza total, cloretos, amônia, sulfato, nitrato, coliformes totais, coliformes termotolerantes, Escherichia coli e bactérias heterotróficas, com frequência mensal nos meses de fevereiro a outubro de 2017, em plena seca de 2011/2017. Foram observadas variações relevantes nos parâmetros da água oriunda dos açudes, principalmente do açude Epitácio Pessoa, em decorrência do aporte de água do rio São Francisco por meio do Projeto de Integração do Rio São Francisco com as Bacias do Nordeste Setentrional (PISF). Os resultados indicaram que não houve variações consideráveis nos parâmetros da água de chuva armazenada nas cisternas. Diferentemente das cisternas com águas de açudes, houve conformidade em relação à Portaria no 5/2017 do Ministério da Saúde para todos os parâmetros físicos e químicos analisados nas cisternas com água de chuva.
\end{abstract}

Palavras-chave: secas; escassez hídrica; carros-pipa; variações de parâmetros de qualidade.

\begin{abstract}
In this work, the temporal evolution of quality parameters and the analysis of the conformity of water stored in cisterns in the municipalities of Barra de Santana, Boqueirão, and Caturité in the semi-arid state of Paraíba are presented. The water stored in the cisterns studied comes from rain and from Epitácio Pessoa fluvial reservoirs in the region of Cariri and Araçagi in the region of Brejo. The parameters analyzed were: $\mathrm{pH}$, turbidity, electrical conductivity, total dissolved solids, total alkalinity, apparent color, total hardness, chlorides, ammonia, sulfate, nitrate, total coliforms, thermotolerant coliforms, Escherichia coli, and heterotrophic bacteria, with monthly frequency in the months of February to October 2017, in the midst of the 2011/2017 drought. Relevant variations were observed in the parameters of the water coming from fluvial reservoirs, mainly from Epitácio Pessoa due to the water supply of the São Francisco river through the São Francisco River Integration Project (Projeto de Integração do Rio São Francisco - PISF). The results indicated that there were no significant changes in rainwater storage parameters in cisterns. Unlike cisterns with water from fluvial reservoirs, there was compliance in relation to Ordinance No. 5/2017 of the Ministry of Health for all the physical and chemical parameters analyzed in cisterns with rainwater.
\end{abstract}

Keywords: droughts; water scarcity; water trucks; variations in quality parameters.

\section{INTRODUÇÃO}

O aproveitamento da água de chuva coletada no telhado das residências e armazenada em cisternas teve grande aceitação por parte da população rural do semiárido e vem sendo utilizada com sucesso no Brasil. Segundo Assis (2012), essa prática ganhou destaque no país a partir das ações lideradas pela Articulação do Semiárido Brasileiro (ASA), por meio do Programa Um Milhão de Cisternas (P1MC).

Embora construídas com a finalidade de captar e armazenar água de chuva, as cisternas podem ser abastecidas por meios artificiais como o carro-pipa, com águas provenientes de açudes ou eventualmente de

'Centro de Tecnologia, Universidade Federal da Paraíba - João Pessoa (PB), Brasil.

*Autor correspondente: tarcisocabral@gmail.com

Fonte de financiamento: Conselho Nacional de Desenvolvimento Científico e Tecnológico - CNPq (Edital Universal 14/2013 - Processo CNPq no 477785/2013-1).

Recebido: 03/10/2018 - Aceito: 05/09/2019 - Reg. Abes: 20180151 
rios. Isso tem ocorrido, pois as águas captadas da chuva, na maioria das vezes, não são suficientes para suprir as necessidades das populações no período de longa estiagem, que atinge grande parte dos meses no Semiárido Brasileiro (SAB) (ANDRADE et al., 2015).

Nos períodos de seca, o abastecimento de água por meio de carros-pipa frequentemente se torna a única opção para pequenos núcleos urbanos e comunidades rurais residentes no SAB. Essa forma de oferta de água é uma ação de mitigação emergencial para enfrentar os impactos negativos decorrentes da escassez hídrica, tendo em vista que é uma ação efetivada após o evento configurado (MACHADO; DIAS; SILVA, 2017).

Imediatamente após a configuração de uma situação de seca, surge a questão de como evitar os impactos negativos às populações, especialmente em relação ao acesso à água. Nesse caso, uma iniciativa implantada como forma de diminuir a vulnerabilidade das famílias rurais e de pequenos núcleos urbanos, frente ao fenômeno da seca que se iniciou em 2011, merece destaque: a Operação Carro-Pipa (OCP) (DINIZ; LIMA, 2017)

A OCP é um programa de mútua cooperação técnica e financeira entre o Ministério da Integração Nacional e o Ministério da Defesa (BRASIL, 2012), gerenciado pelo Ministério da Integração e operacionalizado pelo Exército Brasileiro para realização de ações complementares de apoio às atividades de distribuição de água às populações atingidas por estiagem e seca na região do SAB.

Essa operação faz parte das políticas para o semiárido e o combate à seca em benefício das populações dos municípios que se encontram em situação de emergência ou em estado de calamidade pública. É uma ação de enfrentamento ou uma reação à realidade instalada no momento da situação. Desse modo, também é uma ação de gestão da crise em seca.

Embora a OCP seja o maior programa de distribuição de águas no semiárido durante os períodos de estiagem, também há distribuição de águas pelos estados e municípios por meio de carros-pipa. Além disso, muitos moradores também compram água de vendedores autônomos.

Além dos problemas relativos à disponibilidade de água no $\mathrm{SAB}$, estudos realizados por Souza et al. (2011), Hagemann e Gastaldini (2016) e Machado (2017) apontam para problemas relacionados à qualidade da água.

Relativamente às águas de chuva nas cisternas, há relatos (MENDEZ et al., 2011; SILVA et al., 2017) de que a qualidade pode ser influenciada pela poluição do ar em regiões industriais e pelo sistema de captação (telhados, calhas e superfícies de escoamentos), que permitem a entrada de contaminantes, tanto biológicos quanto não biológicos. Poeira, sujeira, fezes de animais e folhas de árvores podem, além de contaminar a água com microrganismos nocivos à saúde, causar sabores e odores desagradáveis na água.

A água de chuva coletada diretamente da atmosfera é, geralmente, de boa qualidade (ANDRADE NETO, 2013; LUNA et al., 2014).
A contaminação atmosférica da água da chuva, normalmente, é limitada a zonas urbanas e industriais poluídas, e mesmo nesses locais, essa água, quase sempre, apresenta boa qualidade química para vários usos. Gwenzi et al. (2015) afirmam que a água das chuvas não tem uso aconselhado para consumo humano em locais com forte poluição atmosférica, densamente povoados ou industrializados.

De acordo com Gwenzi e Nyamadzawo (2014), alguns cuidados devem ser tomados no intuito de garantir a qualidade da água da chuva armazenada em cisternas. Um deles é descartar as primeiras águas precipitadas, pois contêm impurezas oriundas dos telhados. Para isso, deve ser instalado um dispositivo que permita desviar as águas das primeiras chuvas. Hagemann e Gastaldini (2016) relatam que, em eventos caracterizados por fraca intensidade do início ao fim da precipitação, os valores dos parâmetros de qualidade da água da chuva coletada dos telhados estudados na cidade de Santa Maria, Rio Grande do Sul, foram menores em relação a eventos chuvosos mais intensos e mesmo com maiores períodos secos antecedentes. Além disso, há a indicação da influência do poder de arraste da chuva na qualidade da água coletada.

Já o abastecimento das cisternas com águas oriundas de açudes e transportadas por carros-pipa, embora possa minimizar o problema da escassez de água, torna-se uma fonte potencial de contaminação por fatores ligados à origem da água, pela vulnerabilidade a que a água está exposta, podendo haver o despejo de efluentes nos reservatórios utilizados para sua captação, e pelas condições de higiene e limpeza dos carros-pipa durante o transporte (AMORIM; PORTO, 2003).

A qualidade da água dos açudes pode variar de acordo com a ocupação da bacia hidrográfica em áreas a montante, seu grau de armazenamento, entre outros fatores, além da ocorrência de aporte de águas oriundas de outras bacias, o que deve ser considerado na análise das águas das cisternas, pois podem afetar suas características.

As perdas de água nos reservatórios fluviais por evaporação são bastante significativas no semiárido, uma vez que dependem das influências dos agentes e fatores climáticos, como insolação, umidade relativa, ventos, temperatura do ar, entre outros. As características físicas, químicas e biológicas das águas naturais transcrevem processos ocorrentes nos corpos hídricos como consequência das capacidades de dissolução de ampla gama de substâncias e de transporte pelo escoamento superficial e subterrâneo (LIBÂNIO, 2010).

Autores como Santos, Ceballos e Sousa (2013), Andrade et al. (2015), Machado, Dias e Silva (2017) deixam claro em estudos que a qualidade da água para consumo humano em cisternas abastecidas com águas de açudes é duvidosa se não houver tratamento.

A qualidade da água transportada em carros-pipa é, obviamente, dependente das condições do manancial, de maneira que o grau de tratamento a ser aplicado está diretamente relacionado às suas condições. Gomes et al. (2015) apontam a necessidade de conscientização 
da população atendida quanto à limpeza dos reservatórios para condicionamento da água, tanto dos carros-pipa quanto das cisternas.

A realização de estudos que visem analisar a qualidade das águas armazenadas em cisternas oriundas dessas duas fontes de abastecimento, água de chuva e transportadas de açudes por meio de carros-pipa, incluindo a verificação da conformidade da água com os padrões de potabilidade, é essencial para a definição de ações de planejamento da melhoria das condições de vida e de saúde dos moradores do semiárido.

Portanto, o presente artigo teve como objetivo analisar a qualidade das águas de chuvas e de açudes, armazenadas em cisternas de concreto, em três municípios do semiárido da Paraíba. Além disso, analisou-se a evolução temporal dos parâmetros de qualidade da água de chuva e proveniente de açudes nas cisternas, no período de seca severa em 2017. Também foi feita a verificação da conformidade da qualidade das águas armazenadas em cisternas conforme a Portaria de Consolidação n 5, de 28 de setembro de 2017, do Ministério da Saúde - MS (PRC n 5/2017) (BRASIL, 2017), que estabelece os padrões de potabilidade da água.

\section{METODOLOGIA}

\section{Caracterização das áreas de estudo e das cisternas monitoradas}

As cisternas monitoradas estão localizadas nos municípios de Barra de Santana, Boqueirão e Caturité, no estado da Paraíba. A seleção dos municípios levou em conta a sua inserção no semiárido e a indisponibilidade de sistemas públicos ou privados de abastecimento de água. As amostras de água foram coletadas em 12 cisternas, com frequência mensal, sendo 6 abastecidas com águas de chuva e 6 com águas provenientes dos açudes Epitácio Pessoa e Araçagi, compreendendo o período de fevereiro a outubro de 2017. Os critérios estabelecidos para a escolha das cisternas foram: utilização da água da cisterna para consumo humano, independentemente de sua origem, e não haver mistura de água de chuva com água de açude na cisterna.

A barragem formadora do açude Epitácio Pessoa (Figura 1) foi construída pelo Departamento Nacional de Obras Contra as Secas (DNOCS), sendo iniciada em 1953 com conclusão em 1956. Localiza-se entre o

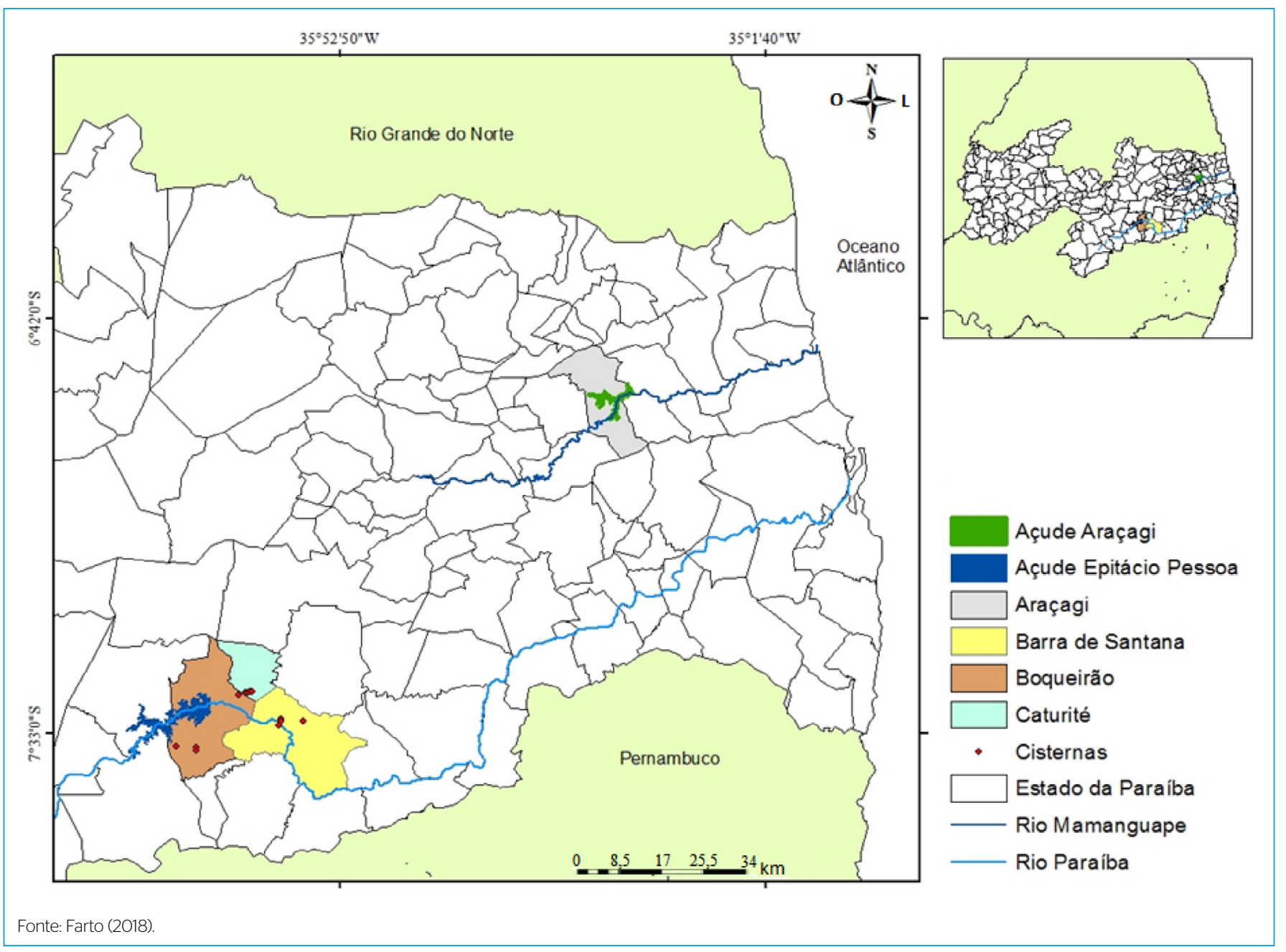

Figura 1 - Localização dos municípios do estudo e posição geográfica das cisternas monitoradas. 
alto e o médio curso do rio Paraíba, na bacia hidrográfica de mesmo nome. É o segundo maior reservatório do estado da Paraíba, estando atrás apenas do açude Coremas/Mãe D’Água. Sua barragem fica no município de Boqueirão, cuja bacia hidráulica se estende para os municípios de Boqueirão, Barra de São Miguel e Cabaceiras.

Quando o reservatório foi construído, a sua capacidade de armazenamento era de 536 milhões $\mathrm{m}^{3}$. Em razão do assoreamento, essa capacidade vem sendo reduzida (PERH, 2006) - atualmente, seu volume máximo de acumulação está estimado em 411,69 milhões $\mathrm{m}^{3}$. O lago formado cobre uma área de 2.680 ha, e a sua bacia hidrográfica compreende a área de $12.410 \mathrm{~km}^{2}$.

Durante a seca 2011-2017, praticamente sem haver escoamento no rio Paraíba contribuindo ao açude Epitácio Pessoa, o volume armazenado diminuiu consideravelmente, chegando a atingir 2,9\% da sua capacidade em abril de 2017 - alcançando, portanto, pela primeira vez, valor menor do que o do volume morto de 6,5\% (Figura 2). Assim, a captação de água para a cidade de Campina Grande e outros centros urbanos menores teve de ser feita com a implantação de bombas hidráulicas flutuantes. Essa situação começou a mudar com o aporte de águas do rio São Francisco, em abril de 2017, como primeiros resultados do Projeto de Integração do Rio São Francisco com as Bacias do Nordeste Setentrional (PISF).

A barragem Araçagi, formadora do açude Araçagi, situa-se no município de Araçagi, na Paraíba (Figura 1). Ela foi construída em 2002 pelo Governo do Estado da Paraíba e o reservatório, no rio Mamanguape, na bacia hidrográfica de mesmo nome, atinge os municípios de Araçagi, Itapororoca e Cuité de Mamanguape.
Esse açude possui capacidade máxima de 63,29 milhões $\mathrm{m}^{3}$, com sangramentos frequentes. No entanto, na seca de 2011-2017 atingiu, em dezembro de 2012, o menor volume registrado: 45 milhões $\mathrm{m}^{3}$.

No ano de 2017, em plena seca, foi registrado no açude Araçagi o volume mínimo de 43,89 milhões $\mathrm{m}^{3}$, equivalente a $69,46 \%$ da sua capacidade, porém bem acima do volume morto (3,2 milhões $\left.\mathrm{m}^{3}\right)$, atingindo seu volume máximo no dia 21 de julho de 2017. De fato, diferentemente do açude Epitácio Pessoa, o comportamento do volume de água armazenado não atinge valores críticos por conta das precipitações que não ficaram abaixo da média a partir de 2015. Houve queda acentuada no volume armazenado no ano de 2017, que foi atribuída à intensa captação de água por carros-pipa para distribuição em municípios de bacias hidrográficas vizinhas, que foram afetadas pela seca (Figura 3).

As cisternas escolhidas foram identificadas por siglas que configuram o seguinte espaço amostral nos municípios: Caturité $-\mathrm{C} 1$, C2, C3 e C4; Boqueirão - C5, C6, C7 e C8; e Barra de Santana - C9, C10, C11 e C12.

O Quadro 1 apresenta informações das cisternas selecionadas, tais como origem da água, construtor, material da tampa, forma de retirada da água e localidade. Todos os proprietários das cisternas informaram realizar limpeza anual. A Figura 4 apresenta a localização geográfica das cisternas e a localização dos postos pluviométricos.

\section{Análises físicas, químicas e microbiológicas}

Os parâmetros $\mathrm{pH}$, turbidez, condutividade elétrica (CE) e sólidos totais dissolvidos (STD) foram medidos in loco por meio da sonda multiparamétrica HANNA ${ }^{\circledR}$ modelo HI 9829. Já os parâmetros alcalinidade total, cor

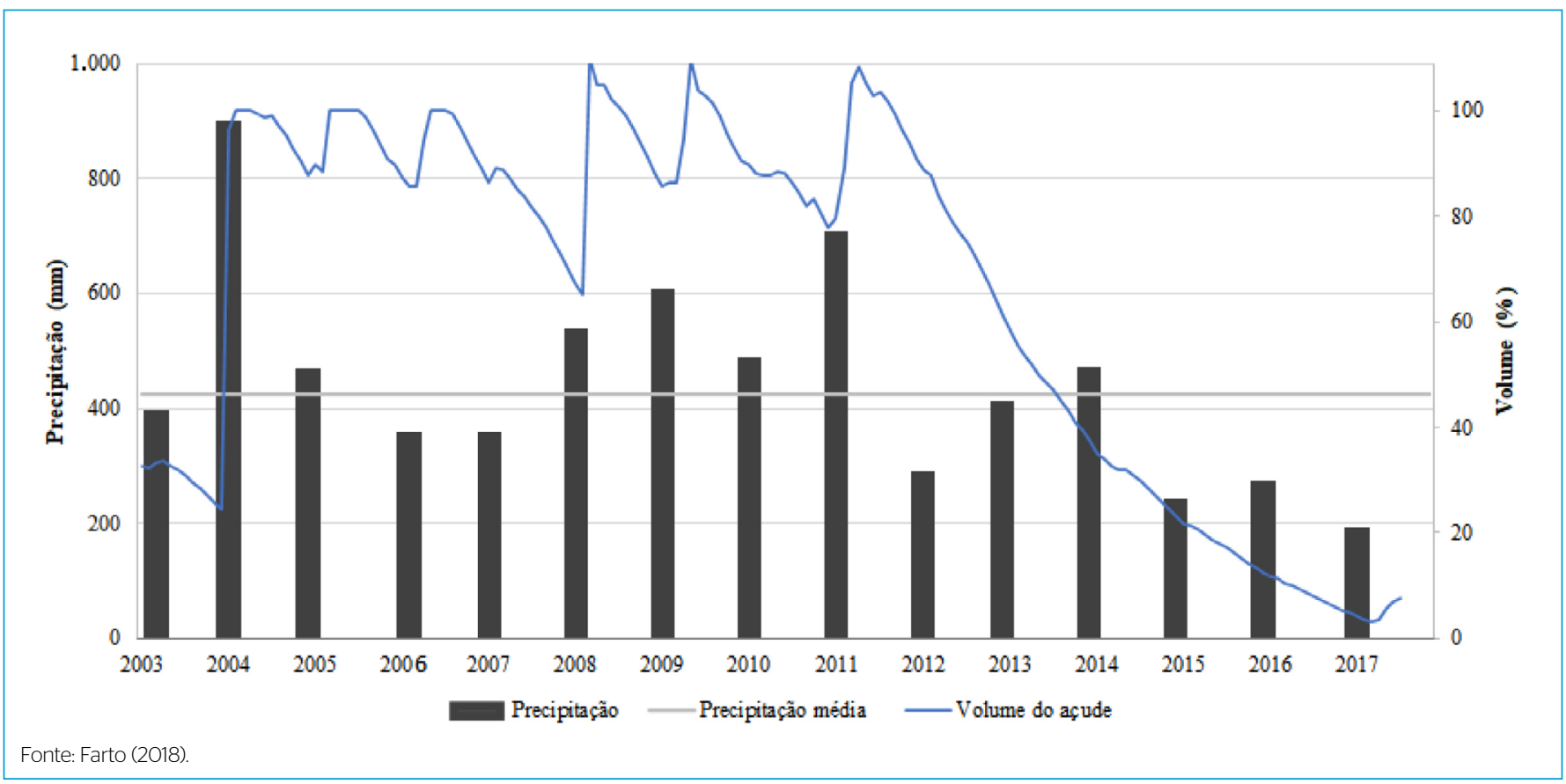

Figura 2 - Precipitação anual em Boqueirão e volumes registrados no açude Epitácio Pessoa. 


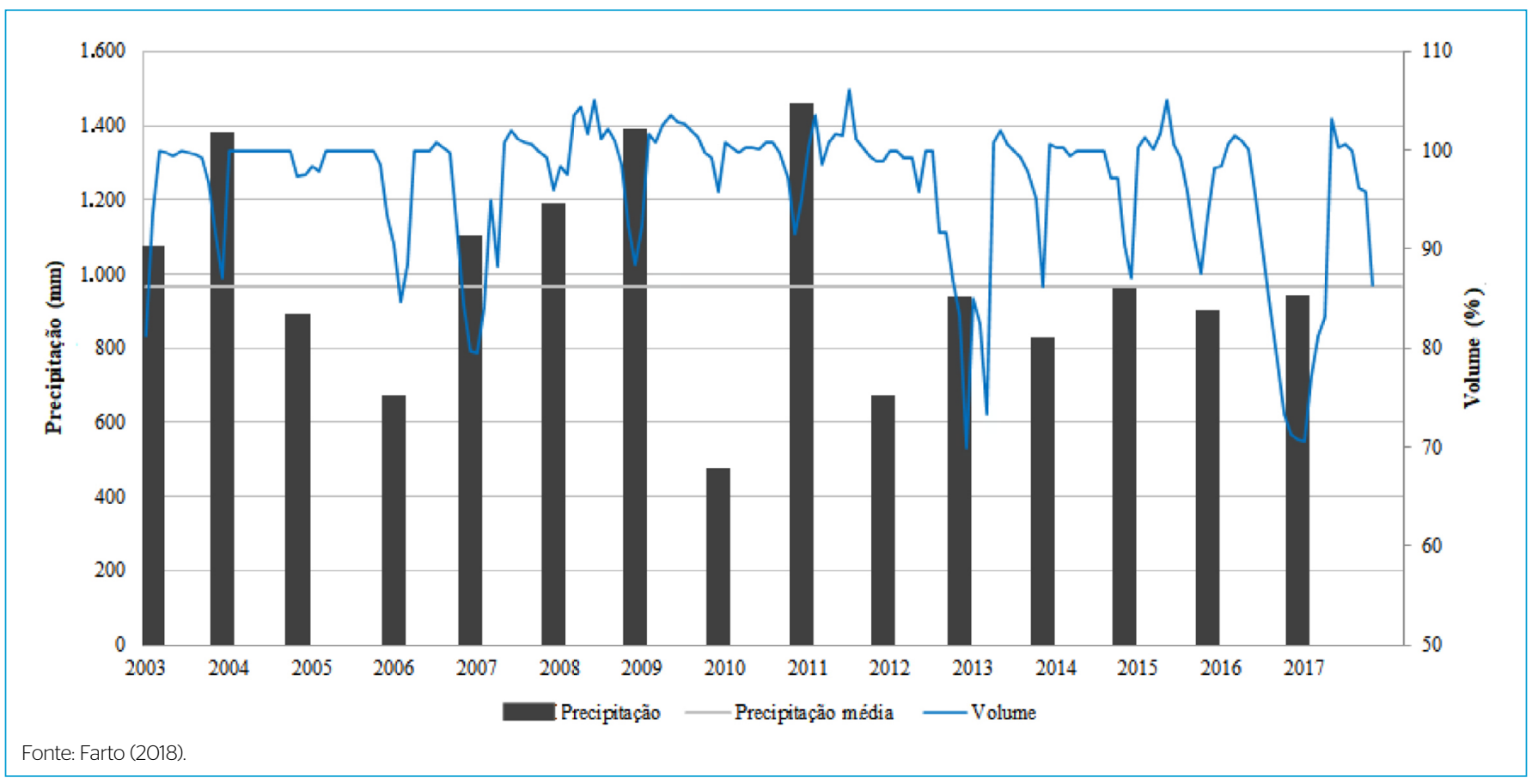

Figura 3 - Precipitação anual em Araçagi e volumes registrados no açude.

Quadro 1 - Caracterização das cisternas selecionadas.

\begin{tabular}{|c|c|c|c|c|c|}
\hline Cisternas & $\begin{array}{l}\text { Origem } \\
\text { da água }\end{array}$ & Construtor & $\begin{array}{l}\text { Tipo de } \\
\text { tampa }\end{array}$ & $\begin{array}{l}\text { Forma de } \\
\text { retirada } \\
\text { da água }\end{array}$ & Localidade \\
\hline $\mathrm{C} 1$ & Chuva & ASA/P1MC & Concreto & Balde & Sítio Ramada \\
\hline $\mathrm{C} 2$ & Chuva & ASA/P1MC & Zinco & Balde & Sítio Ramada \\
\hline C3 & $\begin{array}{l}\text { Açude } \\
\text { Epitácio } \\
\text { Pessoa }\end{array}$ & ASA/P1MC & Zinco & Balde & $\begin{array}{c}\text { Sítio Pedra } \\
\text { D’Água }\end{array}$ \\
\hline C4 & $\begin{array}{c}\text { Açude } \\
\text { Epitácio } \\
\text { Pessoa }\end{array}$ & ASA/P1MC & Madeira & Balde & $\begin{array}{l}\text { Sítio Pedra } \\
\text { D'Água }\end{array}$ \\
\hline C5 & $\begin{array}{l}\text { Açude } \\
\text { Epitácio } \\
\text { Pessoa }\end{array}$ & ASA/P1MC & Zinco & Balde & Sítio Tatu \\
\hline C6 & Chuva & ASA/P1MC & Zinco & $\begin{array}{l}\text { Bomba } \\
\text { manual }\end{array}$ & $\begin{array}{l}\text { Distrito do } \\
\text { Marinho }\end{array}$ \\
\hline $\mathrm{C} 7$ & Chuva & ASA/P1MC & Zinco & $\begin{array}{l}\text { Bomba } \\
\text { manual }\end{array}$ & $\begin{array}{l}\text { Distrito do } \\
\text { Marinho }\end{array}$ \\
\hline C8 & $\begin{array}{l}\text { Açude } \\
\text { Epitácio } \\
\text { Pessoa }\end{array}$ & Particular & Madeira & Balde & Sítio Ramada \\
\hline C9 & $\begin{array}{l}\text { Açude } \\
\text { Araçagi }\end{array}$ & ASA/P1MC & Zinco & Balde & $\begin{array}{c}\text { Sítio Pedra } \\
\text { Azul }\end{array}$ \\
\hline $\mathrm{C} 1 \mathrm{O}$ & $\begin{array}{l}\text { Açude } \\
\text { Araçagi }\end{array}$ & $\begin{array}{c}\text { Prefeitura } \\
\text { de Barra } \\
\text { de Santana }\end{array}$ & Madeira & Balde & $\begin{array}{c}\text { Comunidade } \\
\text { Mulugu }\end{array}$ \\
\hline $\mathrm{C} 11$ & Chuva & Particular & PVC & Balde & Área urbana \\
\hline $\mathrm{C} 12$ & Chuva & Particular & Zinco & Balde & Área urbana \\
\hline
\end{tabular}

ASA: Articulação do Semiárido Brasileiro; P1MC: Programa Um Milhão de Cisternas. aparente, dureza total, cloretos, amônia, sulfato, nitrato, coliformes totais, coliformes termotolerantes, Escherichia coli (E. coli) e bactérias heterotróficas foram objetos de análises realizadas nos laboratórios da Universidade Federal da Paraíba (UFPB), em João Pessoa, de acordo com os procedimentos descritos em American Public Health Association, American Water Works Association e Water Environment Federation (APHA; AWWA; WEF, 2012).

\section{Análise temporal dos parâmetros de qualidade das águas}

Para investigar o comportamento dos valores dos parâmetros de qualidade das águas armazenadas nas cisternas, ao longo do período de estudo, foram feitas separações em três grupos (águas de chuva; águas oriundas do açude Araçagi; e águas oriundas do açude Epitácio Pessoa), buscando facilitar a análise dos dados medidos.

Os parâmetros de qualidade relativos às águas de chuva armazenadas nas cisternas foram plotados em conjunto com os valores das chuvas, relativos aos totais diários precipitados no período de estudo. Os resultados dos parâmetros de qualidade relativos às águas dos açudes foram plotados conjuntamente com os valores percentuais dos volumes dos açudes, ao longo do período estudado. Além disso, realizou-se o cálculo da média móvel de dois períodos, com os valores médios obtidos das medições de cada parâmetro de qualidade, em cada mês.

Os dados pluviométricos e o percentual do volume dos açudes foram obtidos na Agência Executiva de Gestão das Águas (AESA-PB). Foram adotados os dados diários do posto pluviométrico de Boqueirão 


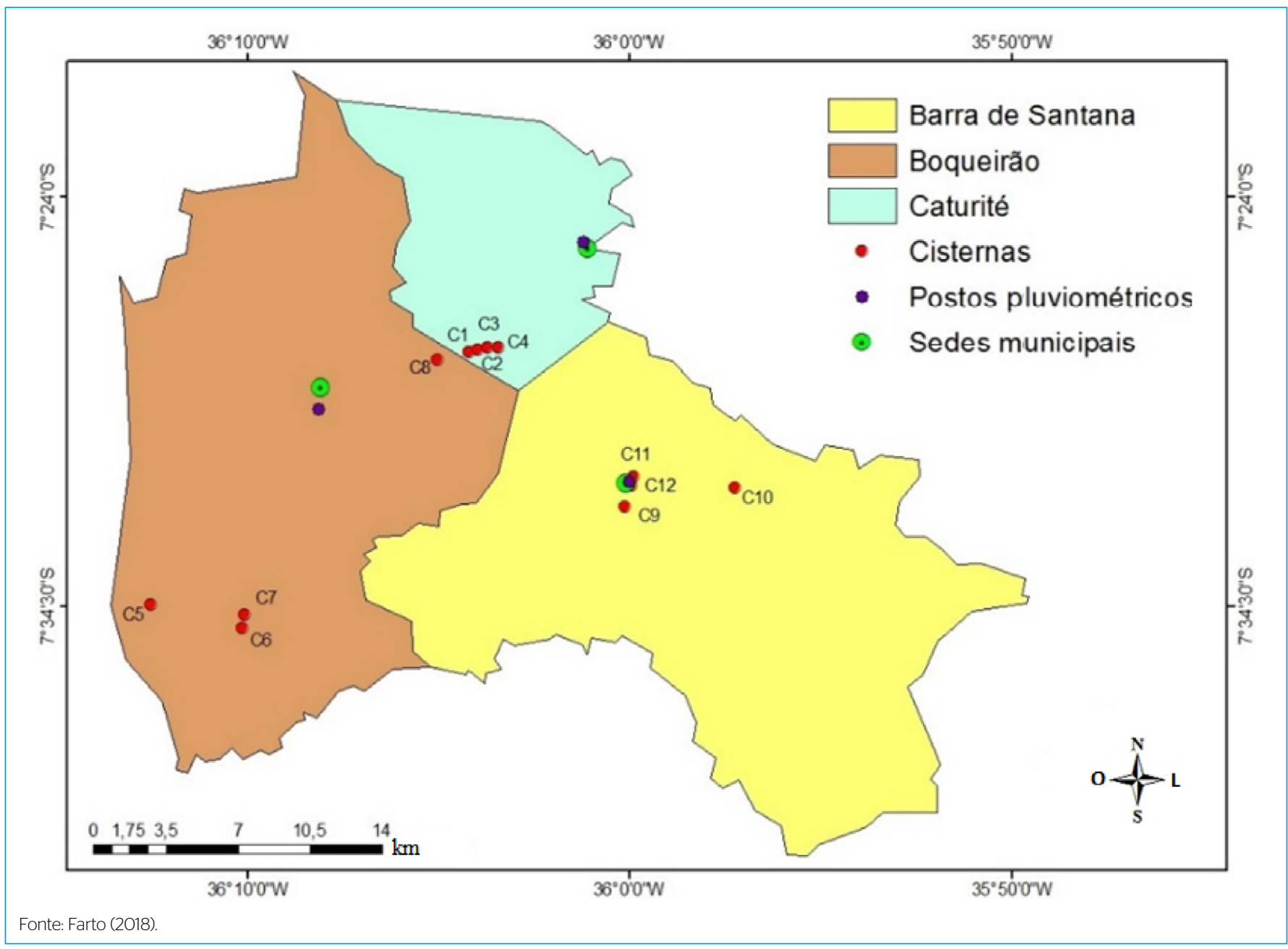

Figura 4 - Posição geográfica das cisternas monitoradas.

por serem considerados de boa qualidade e representativos para os três municípios. Além disso, há falhas no posto pluviométrico do município de Barra de Santana em todo o mês de julho. O posto pluviométrico de Caturité não foi considerado por estar mais distante das cisternas e apresentar valores médios mensais distintos dos outros postos.

\section{Conformidade da qualidade das águas}

Neste estudo, foi realizada a comparação dos valores relativos aos parâmetros de qualidade, obtidos das medições efetuadas nas águas das cisternas, com os padrões de qualidade da água para consumo humano estabelecidos pela Portaria PRC do MS no 5/2017, observando-se os valores máximos e mínimos permitidos.

\section{RESULTADOS E DISCUSSÃO}

Os resultados das medições efetuadas a partir das amostras de água nas cisternas estão apresentados na Tabela 1, em que consta os valores médios mensais dos parâmetros de qualidade das águas de chuva e dos açudes nas cisternas.

\section{Água de chuva}

Observa-se, por meio da Tabela 1, que o parâmetro nitrato foi o único que apresentou valores maiores nas cisternas abastecidas com água de chuva, mesmo com redução após as chuvas de julho.

A análise dos valores dos parâmetros de qualidade da água armazenada nas cisternas indicou que não houve alterações expressivas no período das medições em relação à média para $\mathrm{pH}$, alcalinidade, cloretos, nitrato, turbidez e amônia. As chuvas ocorridas principalmente nos meses de junho e julho não provocaram mudanças perceptíveis nos padrões desses parâmetros de qualidade. A Figura 5 demonstra as variações muito pequenas para o $\mathrm{pH}$, apresentando comportamento similar aos parâmetros anteriormente referidos ao longo do período analisado.

Os valores de CE e STD apresentaram pequena elevação nas médias a partir das chuvas do mês de julho, com comportamento bastante 
Tabela 1 - Valores dos parâmetros e conformidade segundo a origem da água.

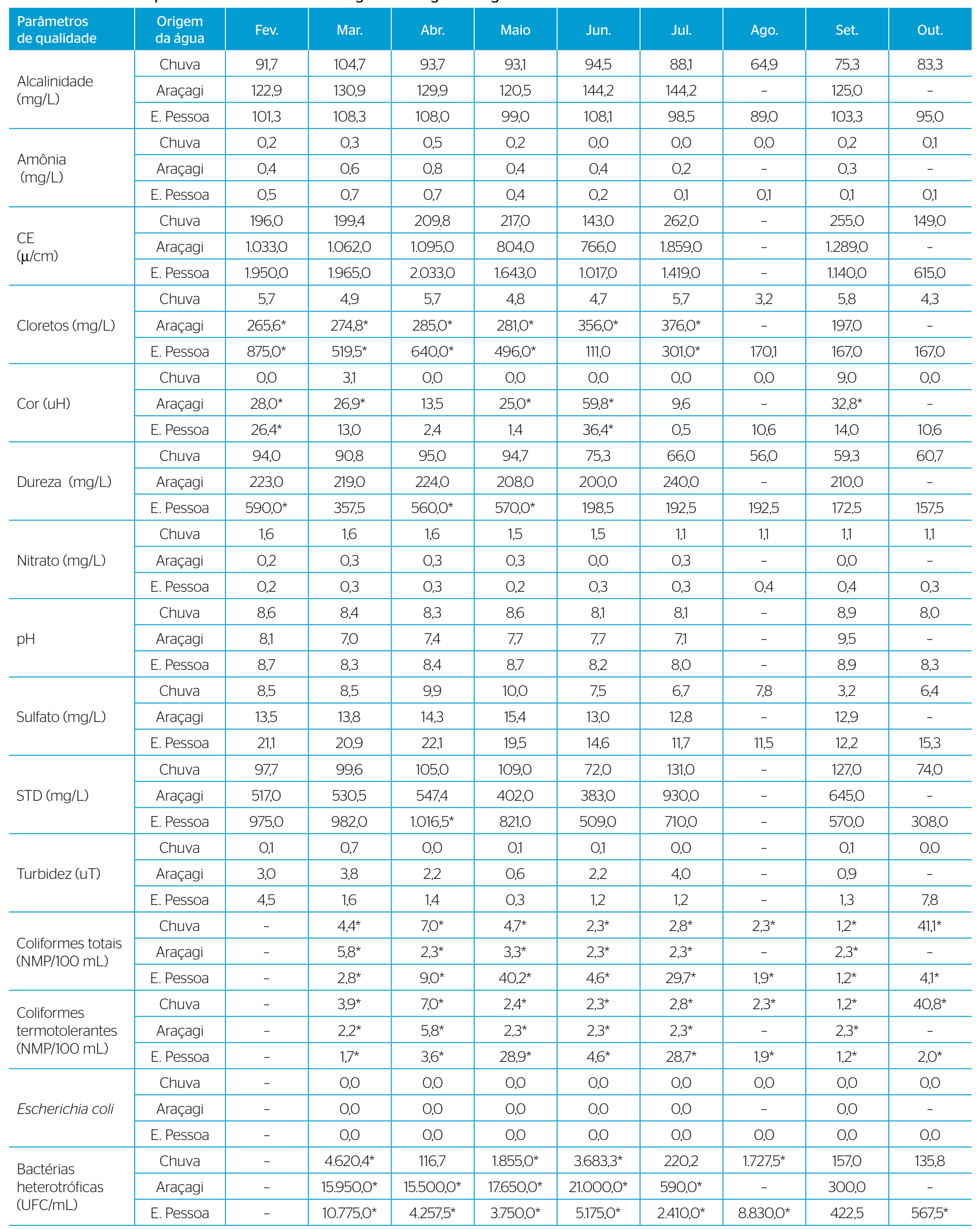

CE: condutividade elétrica; STD: sólidos totais dissolvidos; *não conforme. 


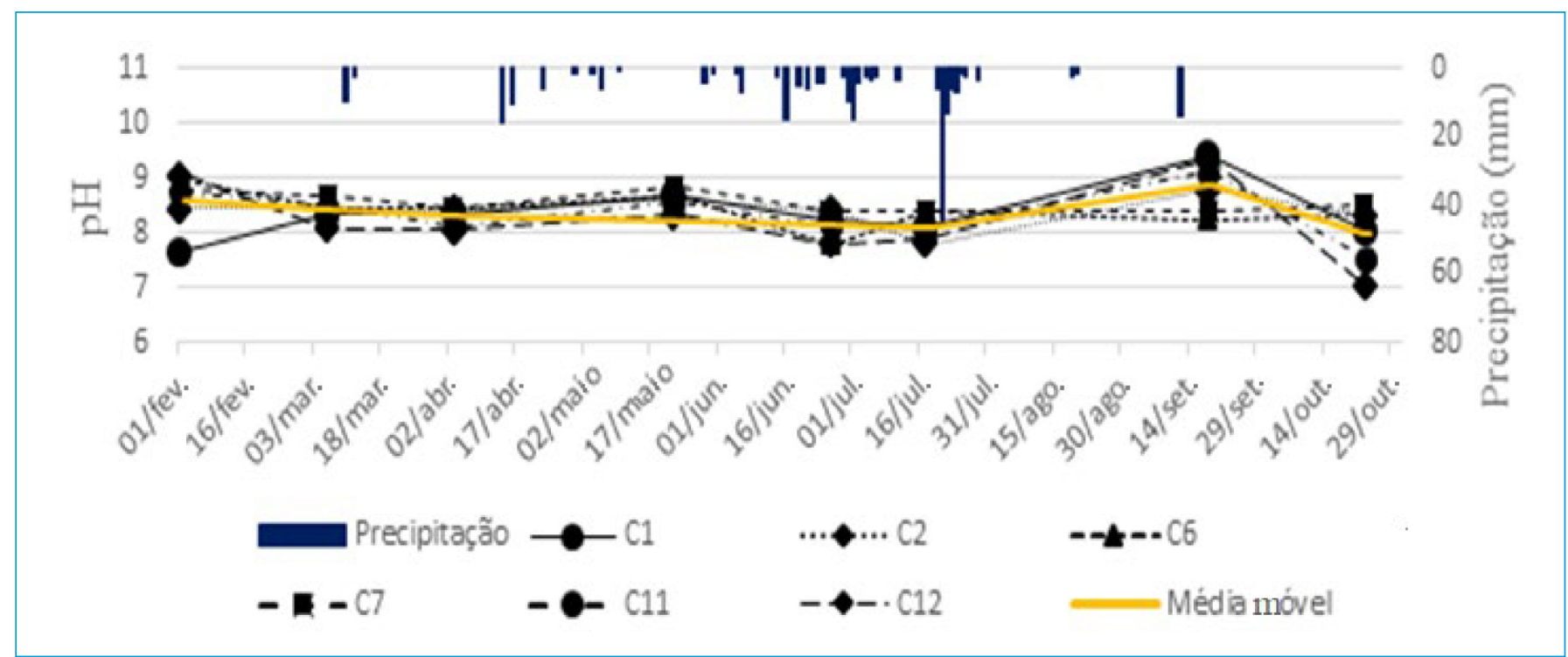

Figura 5 - Variação do pH em cisternas com água de chuva.

semelhante entre si. A Figura 6 demonstra o comportamento da CE, similar ao dos STD ao longo do período analisado.

Pequenas quedas nos valores de dureza e sulfato foram observadas, o que pode ser atribuído às ocorrências de chuvas no mês de julho. A Figura 7 demonstra o comportamento da dureza, similar ao sulfato, ao longo do período analisado. Não houve variações da cor em razão da ocorrência de chuvas, salvo pequenas alterações que ocorreram nos valores medidos nos meses de março e setembro.

Em relação à conformidade, todos os parâmetros físicos e químicos se encontraram dentro dos limites estabelecidos pela Portaria n 5/2017. Porém, os parâmetros microbiológicos, com exceção da E. coli, não se apresentaram em total conformidade com a referida portaria.

Esses valores não conformes encontrados nas águas de chuva nas cisternas podem ser atribuídos à ocorrência de chuvas no período em que houve as medições. Segundo Martinson e Thomas (2003), a qualidade da água das cisternas é fortemente dependente do padrão de chuvas, uma vez que a cada aporte de água há uma possível contaminação bacteriológica nas cisternas, e 90\% das bactérias morrem depois de 48 h da chuva em razão da sedimentação e da falta de luz.

A maioria dos estudos sobre águas de chuva armazenadas em cisternas mostra que essas águas comumente não atendem as recomendações de potabilidade do MS para um ou vários indicadores sanitários, evidenciando que elas estão geralmente contaminadas ou susceptíveis à contaminação por microrganismos patogênicos e que seu consumo direto, sem tratamento, constitui sério risco à saúde humana (VIDAL, 2002; GOULD; NISSEN-PETERSEN, 2002).

Além disso, vários autores brasileiros, especialmente da Região Nordeste, constataram a presença de coliformes em concentrações acima das estabelecidas pelo padrão de potabilidade, em todas as cisternas estudadas (AMORIM; PORTO, 2001; SILVA, 2006; PEREIRA et al., 2007; TAVARES, 2009; VIRIATO, 2011; DIAS, 2016; MACHADO, 2017).

\section{Água do açude Araçagi}

Para as águas oriundas do açude Araçagi armazenadas nas cisternas, houve aumento nos valores dos parâmetros de qualidade referentes à alcalinidade, à CE, aos STD, à dureza, aos cloretos e à turbidez, como resposta ao aumento do volume de água no açude Araçagi, que atingiu $80 \%$ do volume total no período estudado. A Figura 8 demonstra o comportamento da CE, similar aos outros parâmetros referidos.

Comportamento semelhante aos dos parâmetros mencionados anteriormente foi observado para amônia e sulfato, porém com ascensão dos valores no mês de abril e tendência de estabilização com o reservatório cheio a partir do mês de julho, conforme ilustrado na Figura 9 para a amônia, similar ao sulfato, no período analisado.

Não houve variações expressivas para o $\mathrm{pH}$, embora tenha havido registro do valor medido atingindo 9,5, o que foi atribuído ao enchimento do açude. De forma semelhante, não se observam tendências para os parâmetros cor e nitrato em relação à média móvel, ainda que tenham ocorrido valores que sugerem influências do maior volume de água no açude a partir do mês de julho.

Para as bactérias heterotróficas, houve uma clara tendência de queda das concentrações nas cisternas com o aumento do volume de água do açude.

Praticamente não foram percebidas variações dos valores de coliformes totais e termotolerantes no período estudado. No entanto, houve estabilização dos valores a partir do mês de junho. 


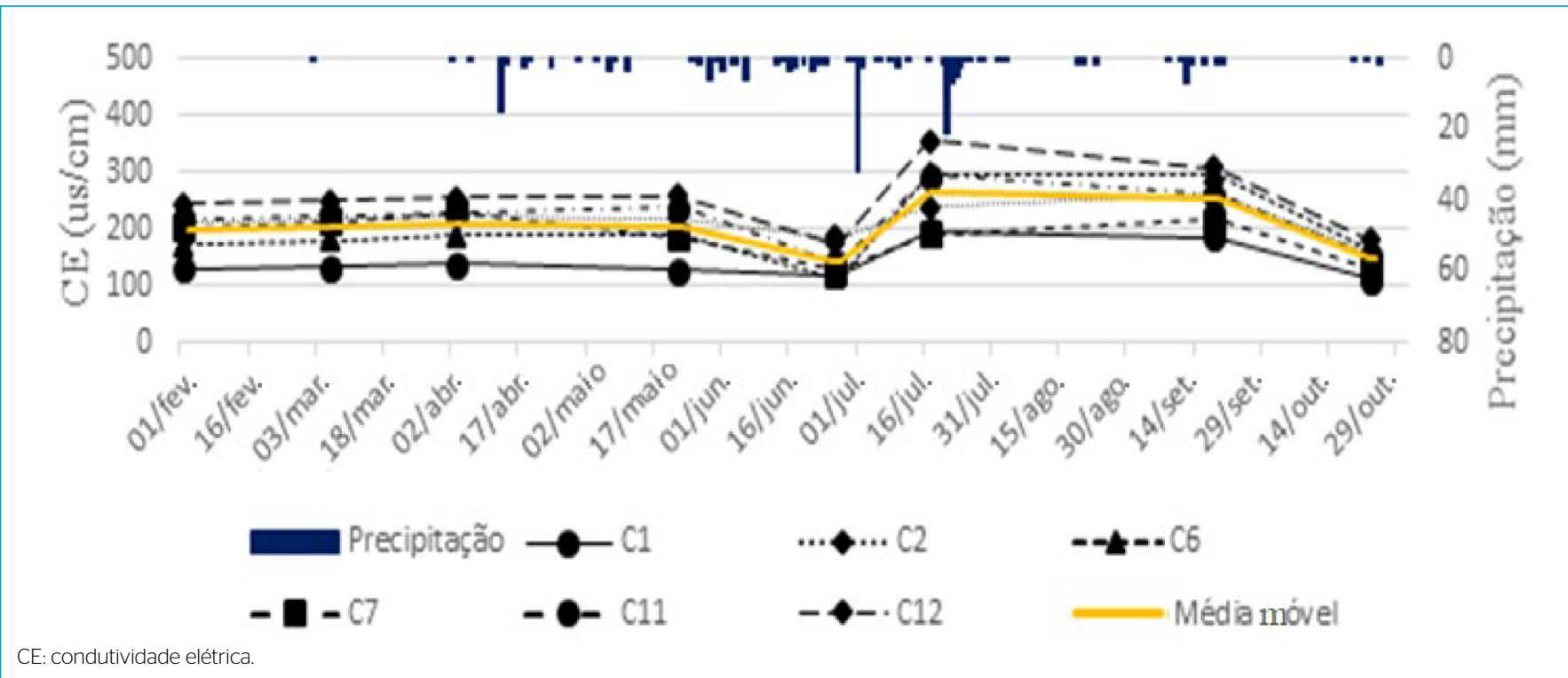

Figura 6 - Variação da condutividade elétrica em cisternas com água de chuva.

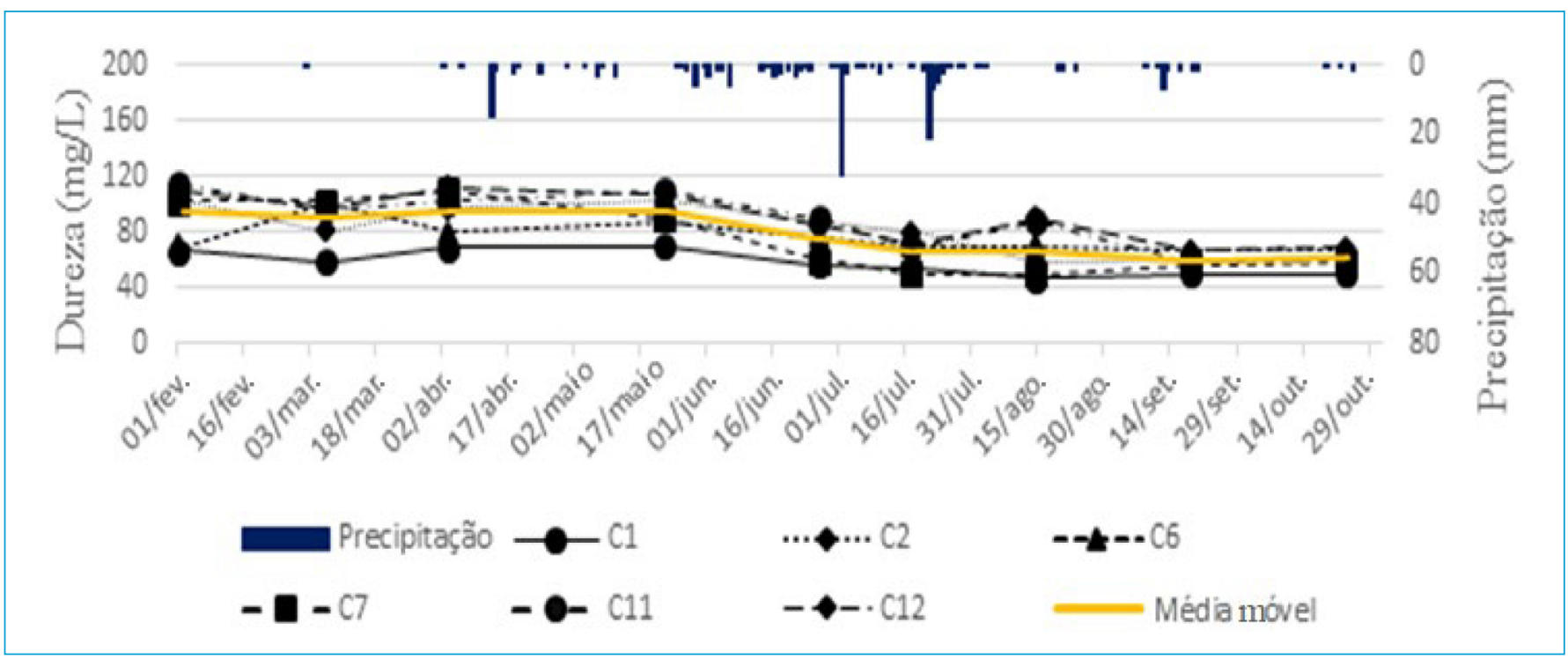

Figura 7 - Variação da dureza em cisternas com água de chuva.

Os maiores valores observados dos parâmetros coliformes totais, termotolerantes e bactérias heterotróficas são atribuídos a problemas nas condições do local de captação de água para o carro-pipa, nas condições de higiene do seu tanque ou no manejo inadequado na retirada da água da cisterna.

\section{Água do açude Epitácio Pessoa}

No mês de abril de 2017, o açude Epitácio Pessoa estava operando com volume dentro da faixa considerada como volume morto, o qual apresenta qualidade da água em condições inferiores às do volume útil. Pôde ser observado também que antes de ocorrer o aporte de águas do PISF no açude, os parâmetros cloretos e dureza não apresentavam conformidade com a Portaria $\mathrm{n}^{\mathrm{o}}$ 5/2017.

Observou-se um comportamento claro de queda dos valores dos parâmetros CE, STD, cloretos, amônia, sulfato e dureza, notadamente a partir de abril de 2017, como resposta ao aumento do volume de água no açude, que ocorreu por meio do aporte de águas do PISF, conforme ilustrado na Figura 10 para os cloretos, de comportamento similar aos outros parâmetros anteriormente referidos.

Vieira e Joaquim Filho (2006) relatam sobre a salinização natural das águas de açudes, poços e barragens do Nordeste do Brasil, associada 


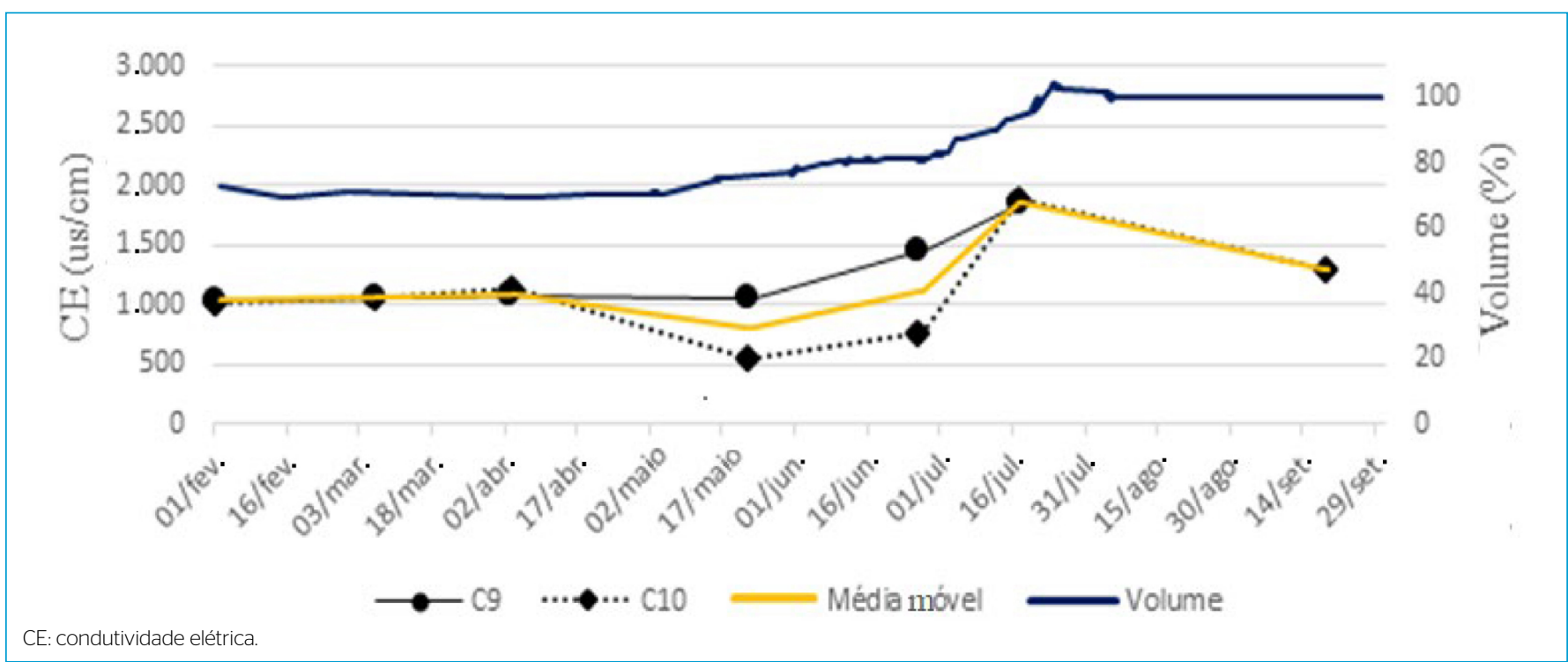

Figura 8 - Variação da condutividade elétrica em cisternas com água oriunda do açude Araçagi.

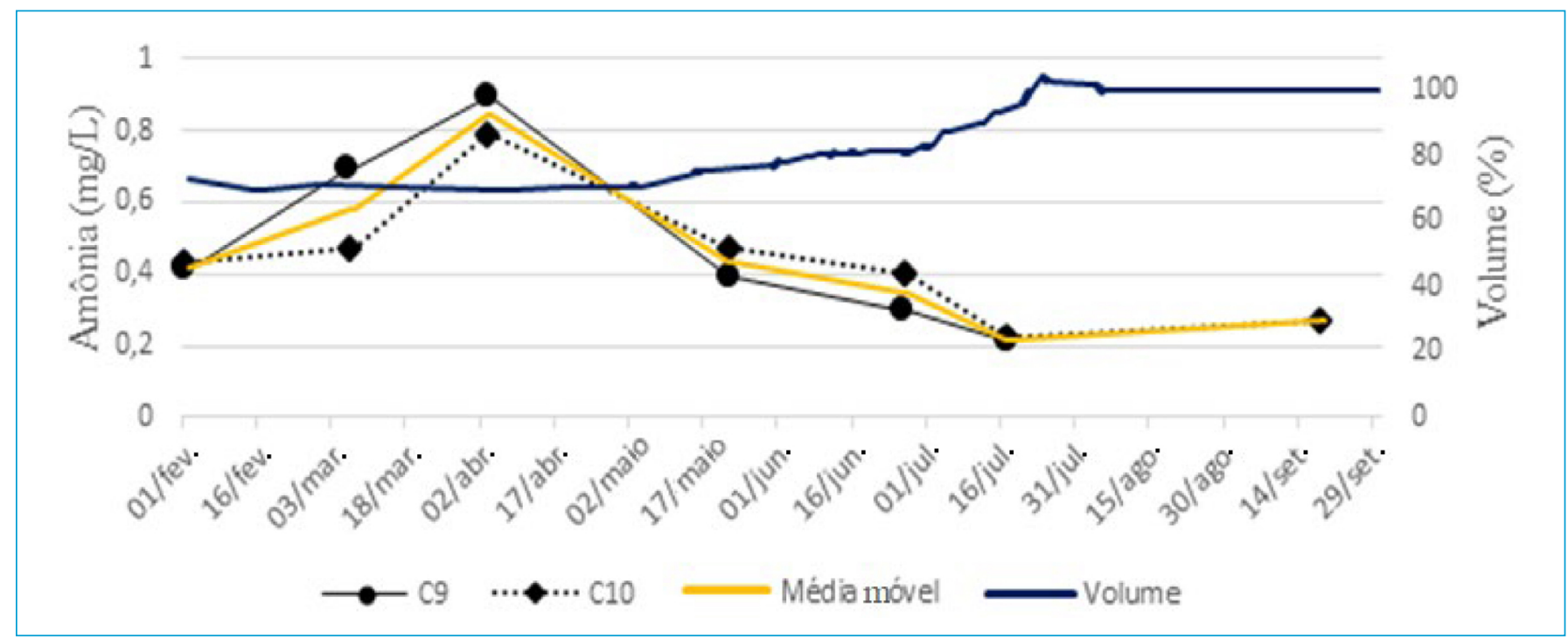

Figura 9 - Variação da amônia em cisternas com água oriunda do açude Araçagi.

às formações geológicas predominantes. Isso explica o fato de as cisternas com águas de açudes apresentarem valores mais elevados de CE quando comparados com os das cisternas com águas de chuva.

Segundo Casali (2008), os valores elevados de STD, encontrados nas águas transportadas por carros-pipa, são decorrentes do maior teor de sais que as águas dos açudes apresentam na sua constituição. Associado a isso estão as condições e os cuidados praticados durante a coleta e o transporte da água, pois a solubilização de componentes ocorre muito facilmente em razão de sua própria constituição e propriedades.

Os resultados dos parâmetros $\mathrm{pH}$ e alcalinidade apresentaram comportamentos semelhantes entre si, para os quais não foram observadas variações expressivas ao longo do tempo de medição, conforme pode ser visto na Figura 11, referente ao pH. Para o parâmetro nitrato, o comportamento também é de pequenas variações, com leve aumento dos valores a partir do mês de maio. $\mathrm{O}$ aumento do volume do açude, iniciado em 19 de abril, não provocou mudanças relevantes nos padrões desses parâmetros de qualidade.

De forma semelhante ao açude Araçagi, os maiores valores observados dos parâmetros coliformes totais, termotolerantes e bactérias heterotróficas também podem ser explicados por problemas nas condições do local de captação de água para o carro-pipa, nas condições de higiene do seu tanque ou no manejo inadequado da retirada da água da cisterna. 


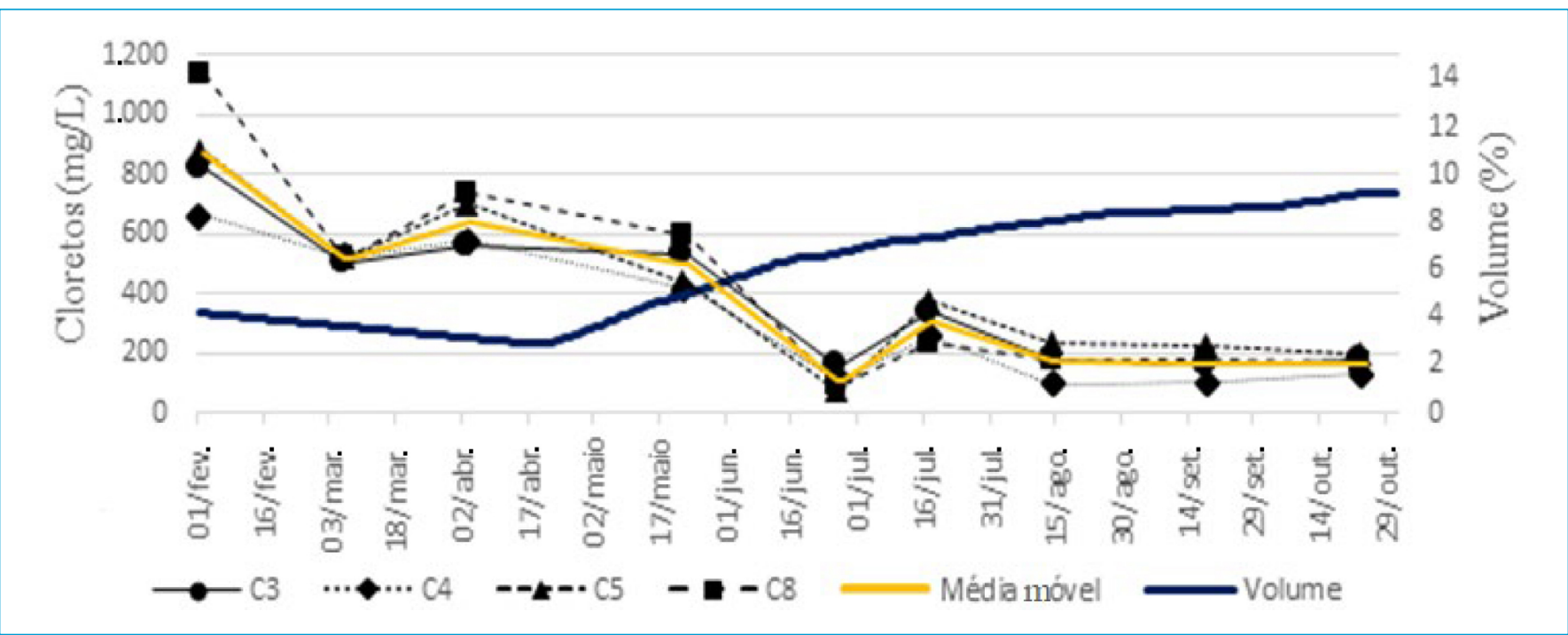

Figura 10 - Variação dos cloretos em cisternas com água oriunda do açude Epitácio Pessoa.

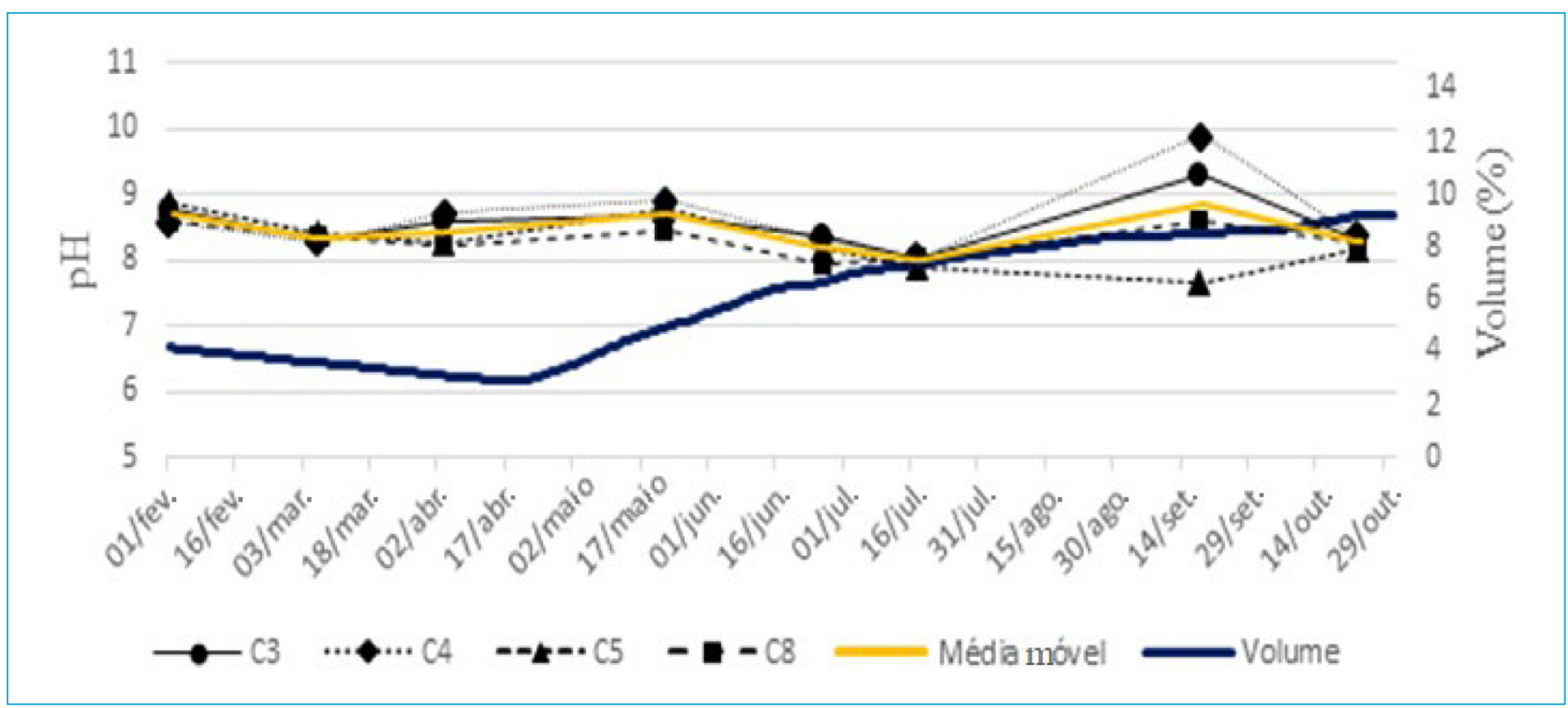

Figura 11 - Variação do pH em cisternas com água oriunda do açude Epitácio Pessoa.

O parâmetro E. coli, durante todo o período de monitoramento das 12 cisternas, com água de chuva ou de açudes, foi o único que não foi detectado em nenhuma amostra de água.

\section{CONSIDERAÇÕES FINAIS}

À luz dos resultados apresentados, com medições em período de seca, para as águas armazenadas em cisternas, pode-se afirmar que as águas de chuva possuem melhor qualidade, uma vez que houve maior ocorrência de valores não conformes com a Portaria no 5/2017 do MS para águas oriundas dos açudes.
No período analisado, houve clara melhoria da qualidade da água, relativamente aos parâmetros físicos e químicos, em decorrência do aporte de águas do rio São Francisco no açude Epitácio Pessoa, principalmente em relação aos parâmetros amônia, CE, cloretos, dureza, sulfato e STD.

Diferentemente do açude Epitácio Pessoa, não houve variações expressivas dos parâmetros físicos e químicos nas águas do açude Araçagi no período analisado, uma vez que o volume armazenado permaneceu muito acima do volume morto, mesmo no ano de 2017, em que ocorreu o segundo menor volume armazenado da série estudada. 
Neste estudo, foi possível concluir que, nas cisternas com água oriunda dos açudes, os parâmetros físicos e químicos que apresentaram maior número de não conformidades foram cloretos, cor e dureza. Já em relação às cisternas com água de chuva, todos os parâmetros físicos e químicos medidos apresentaram conformidade com a Portaria no 5/2017 do MS.

Embora a maioria dos parâmetros tenha apresentado conformidade com os padrões de potabilidade estabelecidos pela Portaria no 5/2017 do MS, principalmente após o aporte de águas do rio São Francisco no açude Epitácio Pessoa, os resultados da qualidade microbiológica obtidos nas cisternas não foram satisfatórios. Houve exceção com a ausência da E. coli, considerada o principal indicador de contaminação fecal recente e de eventual presença de organismos patogênicos.
Com base nos resultados obtidos neste estudo, constata-se a necessidade de monitoramento da qualidade das águas armazenadas nas cisternas analisadas e a adoção de medidas de controle e de prevenção associadas à desinfecção, que são essenciais para assegurar a qualidade adequada para o consumo humano.

\section{AGRADECIMENTOS}

Ao Conselho Nacional de Desenvolvimento Científico e Tecnológico (CNPq) o financiamento da pesquisa sobre qualidade de águas de chuva no semiárido paraibano, realizada na Universidade Federal da Paraíba (UFPB), e à Coordenação de Aperfeiçoamento de Pessoal de Nível Superior (CAPES) a bolsa de estudos concedida à primeira autora.

\section{REFERÊNCIAS}

AMERICAN PUBLIC HEALTH ASSOCIATION (APHA); AMERICAN WATER WORKS ASSOCIATION (AWWA); WATER ENVIRONMENT FEDERATION (WEF). (2012) Standard methods for the examination of water and wastewater. $22^{\mathrm{a}}$ ed. Washington, D.C.: APHA/AWWA/WEF.

AMORIM, M.C.C.; PORTO, E.R. (2001) Avaliação da qualidade bacteriológica da água de cisternas: Estudo de caso no município de Petrolina-PE. In: SIMPÓSIO BRASILEIRO DE CAPTAÇÃO DE ÁGUA DE CHUVA NO SEMIÁRIDO, 2001, Campina Grande. Anais... Campina Grande.

AMORIM, M.C.C.; PORTO, E.R. (2003) Considerações sobre controle e vigilância da qualidade de água de cisternas e seus tratamentos. In: SIMPÓSIO BRASILEIRO DE CAPTAÇÃO E MANEJO DE ÁGUA DE CHUVA, 2003, Juazeiro. Anais... Juazeiro.

ANDRADE, T.S.; NÓBREGA, R.L.B.; RIBEIRO NETO, A.; GALVÃO, C.O. (2015) Estratégias de adaptação e gestão do risco: o caso das cisternas no Semiárido brasileiro. Climacom Cultura Científica Pesquisa, Jornalismo e Arte, v. 2, n. 2.

ANDRADE NETO, C.O. (2013) Aproveitamento imediato da água de chuva. Revista Eletrônica de Gestão e Tecnologias Ambientais, v. 1, n. 1, p. 73-86. http://dx.doi.org/10.17565/gesta.v1i1.7106

ASSIS, T.R.P. (2012) Sociedade civil e a construção políticas públicas na região semiárida brasileira: o caso do Programa Um Milhão de Cisternas Rurais (P1MC). Revista Políticas Públicas, São Luís, v. 16, n. 1, p. 179-189.

BRASIL. (2012) Portaria Interministerial no 1/MI/MD, de 25 de julho de 2012. Dispõe sobre a mútua cooperação técnica e financeira entre o Ministério da Integração Nacional e o Ministério da Defesa, para a realização de ações complementares de apoio às atividades de distribuição de água potável às populações atingidas por estiagem e seca na região do semiárido nordestino e região norte dos Estados de Minas Gerais e do Espírito Santo, denominada
Operação Carro-Pipa, modificada pela Portaria Interministerial n० 2/MI/MD, de 27 de março de 2015. Brasil.

BRASIL. (2017) Ministério da Saúde. Portaria de Consolidação no 5 , de 28 de setembro de 2017. Dispõe sobre a consolidação das normas sobre as ações e os serviços de saúde do Sistema Único de Saúde. Diário Oficial da República Federativa do Brasil, Brasília, n. 190, Seção 1, Suplemento, p. 360.

CASALI, C.A. (2008) Qualidade da água para consumo humano ofertada em escolas e comunidades rurais da região central do Rio Grande do Sul. 173f. Dissertação (Mestrado em Ciências do Solo) Programa de Pós-Graduação em Ciências do Solo, Universidade Federal de Santa Maria, Santa Maria.

DIAS, J.T. (2016) Avaliação de parâmetros físico-químicos e microbiológicos da água armazenada em cisternas de placas e de polietileno no agreste paraibano. Dissertação(Mestradoem Engenharia Civil e Ambiental) - Programa de Pós-Graduação em Engenharia Civil e Ambiental, Universidade Federal da Paraíba, João Pessoa.

DINIZ, P.C.O.; LIMA, J.R.V. (2017) Mobilização social e ação coletiva no Semiárido Brasileiro: convivência, agroecologia e sustentabilidade. Redes, Santa Cruz do Sul, v. 22, n. 2, p. 189-2017 http://doi.org/10.17058/redes.v22i2.9353

FARTO, C.D. (2018) Análise comparativa da qualidade da água de chuva e de açudes armazenada em cisternas na região do Cariri Oriental no estado da Paraíba. Dissertação (Mestrado em Engenharia Civil e Ambiental) - Programa de Pós-Graduação em Engenharia Civil e Ambiental, Universidade Federal da Paraíba, João Pessoa.

GOMES, F.B.M.; COSTA, J.S.; SILVA, A.K.M.; PAULA, D.P. (2015) Análise da qualidade ambiental das águas armazenadas em cisternas no semiárido cearense: uma abordagem multidisciplinar. In: ENCONTRO NACIONAL DA ANPEGE, 11., 2015, Presidente Prudente. Anais... Presidente Prudente. 
GOULD, J.; NISSEN-PETERSEN, E. (2002) Rainwater catchment systems for domestic supply - design, construction and implementation. Londres: ITDG. 356 p.

GWENZI, W.; DUNJANA, N; PISA, C:; TAURO, T.; NYAMADZAWO, G. (2015) Water quality and public health risks associated with roof rainwater harvesting systems for potable supply: Review and perspectives. Sustainability of Water Quality and Ecology, v. 6, p. 107-118. https://doi.org/10.1016/j.swaqe.2015.01.006

GWENZI, W.; NYAMADZAWO, G. (2014) Hydrological impacts of urbanization and urban roof water harvesting in water-limited catchments: a review. Environmental Processes, v. 1, p. 573-593. https://doi.org/10.1007/s40710-014-0037-3

HAGEMANN, S.E.; GASTALDINI, M.C.C. (2016) Variação da qualidade da água de chuva com a precipitação: aplicação à cidade de Santa Maria - RS. Revista Brasileira de Recursos Hidricos, v. 21, n. 3, p. 525-536. http://doi.org/10.1590/2318-0331.011615010

LIBÂNIO, M. (2010) Fundamentos de qualidade e tratamento de água. 3. ed. Campinas: Átomo.

LUNA, Y.H.D.M.; SANTANA, N.C.B.; ATHAYDE JÚNIOR, G.B.; ANJOS JÚNIOR, H. (2O14) Qualidade da água de chuva em João Pessoa: estudo comparativo com diversos padrões de qualidade conforme os usos pretendidos para água em edificações residenciais. Revista Eletrônica de Gestão e Tecnologias Ambientais, v. 2, n. 1, p. 53-68. http://doi.org/10.17565/gesta.v2i1.8792

MACHADO, T.T.V. (2017) Qualidade da água de chuva armazenada em cisternas de placas e de polietileno no semiárido do estado da Paraíba. Tese (Doutorado em Desenvolvimento e Meio Ambiente) - Universidade Federal da Paraíba, João Pessoa.

MACHADO, T.T.V.; DIAS, J.T.; SILVA, T.C. (2017) Evolução e avaliação das políticas públicas para a atenuação dos efeitos da seca no semiárido brasileiro. Gaia Scientia, v. 11, n. 2, p. 84-103. https://doi. org/10.22478/ufpb.1981-1268.2017v11n2.31831

MARTINSON, D.B.; THOMAS, T. (2003) Better, Faster, Cheaper; Research into roofwater harvesting for water supply in low-income countries. Austin: ARCSA.

MENDEZ, C.B.; KLENZENDORF, J.B.; AFSHAR, B.R.; SIMMONS, M.T.; BARRETT, M.E.; KINNEY, K.A.; KIRISITS, M.J. (2011) The effect of roofing material on the quality of harvested rainwater. Water Research, v. 45, n. 5, p. 2049-2059. https://doi.org/10.1016/j. watres.2010.12.015

PEREIRA, F.; BRAGA, C.; SILVA, A.; AMÉRICO, J. (2007) Análise da qualidade e do armazenamento da água consumida na antiga escola agrícola de Ceará-Mirim/RN. In: CONGRESSO DE PESQUISA
E INOVAÇÃO DA REDE NORTE NORDESTE DE EDUCAÇÃO TECNOLÓGICA, 2007, João Pessoa. Anais... João Pessoa.

PLANO ESTADUAL DE RECURSOS HÍDRICOS DO ESTADO DA PARAÍBA (PERH). (2006) Plano Estadual de Recursos Hidricos do estado da Paraíba. Resumo Estendido. Disponível em: <http://www. aesa.pb.gov.br/aesa-website/documentos/plano-estadual/resumoestendido/>. Acesso em: 16 mar. 2018.

SANTOS, A.C.; CEBALLOS, B.S.O.; SOUSA, C.M. (2013) Políticas públicas de água e participação no semiárido: limites e tensões no P1MC. Revista Eletrônica de Gestão e Tecnologias Ambientais, v. 1, n. 1, p. 145-161. http://doi.org/10.17565/gesta.v1i1.8279

SILVA, C.V. (2006) Qualidade da água de chuva para consumo humano armazenada em cisternas de placa. Estudo de caso: Araçuaí, MG. 2006. Dissertação (Mestrado em Saneamento, Meio Ambiente e Recursos Hídricos) - Escola de Engenharia da Universidade Federal de Minas Gerais, Belo Horizonte.

SILVA, S.T.B.; ARAÚJO, L.F.; ALMEIDA, A.J.G.A.; GAVAZZA, S.; SANTOS, S.M. (2017) Comportamento de dispositivos de desvio das primeiras águas de chuva como barreiras sanitárias para proteção de Cisternas. Águas Subterrâneas, v. 31, n. 2, p. 1-11. https:// doi.org/10.14295/ras.v31i2.28658

SOUZA, S.H.B.; MONTENEGRO, S.M.G.L.; SANTOS, S.M.; PESSOAS, S.G.S.; NÓBREGA, R.L.B. (2011) Avaliação da qualidade da água e da eficácia de barreiras sanitárias em sistemas para aproveitamento de água de chuva. Revista Brasileira de Recursos Hídricos, v. 16, n. 3 , p. 81-93. http://dx.doi.org/10.21168/rbrh.v16n3.p81-93

TAVARES, A.C. (2009) Aspectos Físicos, Químicos e Microbiológicos da Água Armazenada em Cisternas de Comunidades Rurais no Semiárido Paraibano. Dissertação (Mestrado em Desenvolvimento e Meio Ambiente) - Universidade Estadual da Paraíba, Campina Grande.

VIDAL, R.T. (2002) Agua de lluvia, agua saludable (manual de mantenimiento del sistema de captación de agua de lluvia). Proyeto de Apoyo a la Reforma del Sector Saluden Guatemala - APRESAL, Comisión Europea. Guatemala: República de Guatemala. 108 p.

VIEIRA, V.P.P.B.; JOAQUIM FILHO, C.G.G. (2006) Água doce no Semiárido. In: REBOUÇA, A.C.; BRAGA, B.; TUNDISI, J.G. (org.). Águas doces no Brasil: capital ecológico, uso e conservação. 3. ed. São Paulo: Escrituras. p. 481-505

VIRIATO, C.L. (2011) Caracterização físico-química e bacteriológica da água armazenada em cisternas no semiárido paraibano. Monografia (Especialização em Geociência e Recursos Hídricos do Semiárido) -Universidade Estadual de Campina Grande, Campina Grande. 